\title{
УOBOЗНАВCTBO. ПUTEDATУРOЗНАВCTBO
}

\author{
УДК 811.161.2 \\ DOI https://doi.org/10.24919/2308-4863/42-2-12
}

\author{
Катерина ЛАДОНЯ, \\ orcid.org/0000-0002-1863-0428 \\ аспірант \\ Інституту філології Київського університету імені Бориса Грінченка, \\ науковий співробітник
}

Інституту педагогіки Національної академії педагогічних наук Украӥни

(Київ, Україна) ladonyaku@ukr.net

\section{НЕУЗУАЛЬНІ СПОСОБИ СЛОВОТВОРУ ОКАЗІОНАЛІЗМІВ УКРАЇНСЬКОМОВНОГО СЕГМЕНТА ҒАСЕВООК}

\begin{abstract}
У статті зазначено, щзо мова інтернет-комунікацій, зокрема мова сочіальної мережі Fасеbоок відзначається значним поширенням неологізмів, створених за допомогою неузуальних способів словотвору, проаналізовано неузуальні неологізми (оказіоналізми), наявні в українськомовному сегменті соціальної мережі Fасеbоок та способи їх утворення. 3'ясовано, щзо поява таких неологізмів - виразна ознака мовного оформлення процесів інтернеткомунікації. У процесі дослідження визначено, щяо основними способами їх утворення є субституція компонентів слова, графічна деформачія, графічна гебридизачія, зокрема грамредуплікачія слова. Проаналізовано найтиповіші випадки їх утворення і функціонування в украӥнськомовному сегменті Facebook.

Зроблено висновок, щу поява інтернет-комунікації-нової сфери використання мови - ставить перед мовною системою проблему ї̈ пристосування до нових умов існування, спричиняє відповідні зміни в лінгвосистемі, які найвиразніше помітні на рівні графіки. Вираження усного мовлення за допомогою писемного посилює роль графічного рівня мови у процесі комунікації, уможливлює використання графічних прийомів як стилістичних засобів увиразнення усно-письмового мовлення інтернет-дискурсу. Для втілення власних інтенцій учасники інтернеткомунікації все частіше полишають межі наявних у мові норм, що може породжувати нову системність, закріплення як нормативних нових прийомів. Натепер комунікація в інтернеті (зокрема, у соиіальних мережах) є тим полігоном, де випробовуються нові можливості графічної системи.

Графічні маніпуляиї з формою слова, які були виявлені у процесі дослідження, мають різноплановий характер. Вони демонструють багатий потенціал, наявний у графічній системі мови.

Ключові слова: графічні неологізми, оказіоналізми, неузуальні способи утворення неологізмів, інтернет-комунікація, сочіальна мережа Facebook.
\end{abstract}

Kateryna LADONIA, orcid.org/0000-0002-1863-0428

Post-graduate Student

Institute of Philology of Borys Grinchenko Kyiv University,

Researcher

Institute of Pedagogy of National Academy of Pedagogical Sciences of Ukraine

(Kyiv,Ukraine)ladonyaku@ukr.net

\section{UNUSUAL WAYS OF WORD FORMATION OF OCCASIONALISMS OF THE UKRAINIAN-SPEAKING SEGMENT OF FACEBOOK}

The article notes that the language of Internet communications, in particular the language of the social network Facebook, is marked by a significant spread of neologisms created using non-usual ways of word formation, analyzes non-usual neologisms (occasionalisms) available in the Ukrainian segment of the social network Facebook and ways of their formation. It was found that the appearance of such neologisms is a clear sign of the language design of Internet communication processes. In the course of the research it was determined that the main ways of their formation are substitution of word components, graphic deformation, graphic hybridization, in particular gram reduplication of a word. The most typical cases of their formation and functioning in the Ukrainian-language segment of the social network Facebook are analyzed.

It is concluded that the emergence of Internet communication - a new field of language use - poses a problem to the language system to adapt to new living conditions, causes appropriate changes in the linguistic system, which are most noticeable at the level of graphics. The expression of oral speech with the help of written strengthens the 
role of the graphic level of language in the process of communication, allows the use of graphic techniques as stylistic means of expressing oral-written speech of Internet discourse. In order to realize their own intentions, the participants of Internet communication increasingly leave the boundaries of the norms available in the language, which can generate a new system, consolidation as normative new methods. Today, communication on the Internet (in particular - in social networks) is the testing ground where new features of the graphics system are being tested.

Graphic manipulations with the form of the word, which were discovered in the process of research, are multifaceted. They demonstrate the rich potential of the graphic language system.

Key words: graphic neologisms, occasionalisms, unusual ways of neologism formation, Internet communication, social network Facebook.

Постановка проблеми. Натепер мова інтернет-комунікацій, зокрема мова соціальної мережі Facebook, відзначається значним поширенням неологізмів, створених за допомогою неузуальних способів словотвору (Штукарева, 2012: 298). Поява таких неологізмів - виразна ознака мовного оформлення процесів інтернет-комунікації. Якщо говорити про соціальну мережу у зв'язку з її жанровою належністю до згаданого типу комунікації, то тут варто зауважити, що вона має певну тематику, комунікативні цілі та стилістичні особливості. Вираження усного мовлення за допомогою писемного виявляється «на всіх рівнях структурної організації зазначеного жанру: фонетичному, граматичному, лексичному, синтаксичному і графічному» (Дзюбіна, 2016: 74), що посилює роль графічного рівня мови у процесі комунікації, уможливлює використання графічних прийомів як стилістичних засобів увиразнення усно-письмового мовлення інтернет-дискурсу.

Водночас згадані тенденції перебувають у руслі загального розвитку комунікативних процесів, що відбуваються 3 використанням писемної мови. Зокрема, С. Мельник у дослідженні української постмодерністської прози в лінгвальному аспекті відзначає «розширення використання графічних засобів різних знакових систем, що $є$ семантично вагомими для розкриття змісту тексту, актуалізації обраної інформації тощо. Такі графічні елементи поки належать до нетрадиційних засобів творення мовної гри, помітно підвищують експресивність тексту та формують нові смисли. Лінгвістичні ігри стають «стихією українських сучасних авторів», дають змогу митцям вислизнути 3-під влади офіційної культури і звільнитися від ідолів і масок тоталітарного минулого. Завдяки чому література водночас стає діалогічною і навіть полілогічною, а «мовний потік набуває форми тілесності». У мові сучасних письменників фіксуємо лексеми, до складу яких входять, окрім букв кирилиці, графічні знаки, цифри, символи чи виділені графічно (за допомогою шрифту, латини) сегменти - слова і частини слів» (Мельник, 2014: 121).

Аналіз досліджень. Інтернет як нове комунікативне середовище, що стрімко розвивається, і мова інтернет-спілкування стали предметом дослідження українських i зарубіжних учених, серед яких О. М. Галичкина, О. І. Горошко, М. Б. Бергельсон, А. С. Войскунский, С. С. Данилюк, Л. Ю. Іванов, П. Є. Кондрашов, Л. Ю. Щипіцина, Г. М. Трофимова, С. Г. Чемеркін Т. В. Яхонтова, G. Barbatsis, D. Crystal, S. Herring, R. Holt, A. Iskold, K. Ryan та інші. Але, на жаль, «функціонуванню української мови в інтернеті сьогодні приділяється мало уваги. Не досить досліджена сама система мови в інтернеті, неактивно вивчаються іiі соціальні різновиди, практично немає наукових праць із вивчення комунікативного аспекту» (Чемеркін, 2009: 7).

Мета статті - проаналізувати неузуальні (графічні) неологізми, зокрема оказіональні, українськомовного сегмента Facebook, визначити основні способи їх творення.

Виклад основного матеріалу. Нові слова у Facebook можуть утворюватися шляхом субституції компонентів слова: у твірній лексичній одиниці відбувається заміна відповідного структурного компонента. А. Тепшич кваліфікує субституцію як заміну місцями морфем або елементів слів та вважає iї продуктивним прийомом мовної гри на рівні словотвору (Тепшич, 2017: 57).

В. Замальдінов кваліфікує такі процеси як «замінну деривацію». Така «ігрова оказіональна номінація», як зазначає дослідник, виникає в результаті заміни у вихідному слові кореневої або іншої неформантної частини. Новоутворення, сформовані таким способом, грунтуються на ефекті невиправданого очікування, вони є засобом іронічного оцінювання, демонстрації креативності та відходу від клішованості (Замальдинов, 2020: 85-86).

У процесі такої «замінної деривації» похідне слово «паронімізується» із твірним, перетворюється на нову / оказіональну мовну одиницю 3 новим лексичним значенням.

Цей компонент-субститут може дорівнювати:

а) одній літері: Андрій Сур. Терміново робіть спеивипуск «Трос Соросят». Руслан Русин. Ви мали на увазі, щзо ми вийшли з ЛОХдауну, так? Энбулатов Эдуард. А наріт хай з себе дурнів сміється; 
б) кільком літерам, що не мають смислової єдності: Mykola Kozak. Швабода у своєму дусі. Провокатори кремлівські. Roman Kolomiiets. Усе сталося так, як і мало бути: усі погані, Сергій Притула - канхветка. В'ячеслав Васильченко Тепер пощчастило ще й стати в його фільмі «Будинок «Слово»» «актором масових сиен». Драйхв і Кайхв))));

в) кільком літерам, що утворюють смислову єдність: Леонід Мефодовський. Що ти людей годуєш трепотнею, говнокомандувач??? Victor Mogull. Haшi поцріоти тупі, як бультерьєр...)). Олекса Правдич. Судячи із профнастилізова-

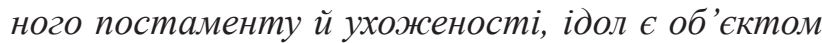
поклоніння місиевих ватопітеків та совкомастурбантропів;.

Як різновид графічної субституції можемо розглядати заміну малих літер великими (капслокізація). Зважаючи на той факт, що письмовий текст у комунікації, яка відбувається в соціальних мережах, використовується для подання 95\% інформації, «учасники інтернет-спілкування вишукують засоби втілення своїх різнопланових інтенцій. Одним із таких засобів виступає «капслокізація». Походить це слово від лексеми «капслок», утвореної на грунті англійського скорочення Caps Lock, яке виводиться 3 Capitals lock («фіксація великих літер»). Caps Lock називають клавішу комп'ютерної клавіатури, за допомогою якої здійснюється фіксація зміни регістра літер (із маленьких на великі й назад)» (Андреєва, 2019: 8).

Капслокізація має на меті зробити смисловий чи логічний наголос на окремому компоненті слова чи речення. Вона представлена такими способами:

a) одна літера (так позначається межа нового формально-смислового фрагмента): Oleg Kyl. Дi наКивав п'ятами зі Львова? То неправда, трохи пожсиував, переїхав в Полтаву і дожив до 1992 p. Lit Klub. Я теж із 25\%. I ие аж ніяк не підстава вірити на слово $\boldsymbol{C}_{\boldsymbol{B}}$ Сол;

б) виділення морфеми: Ostap Drozdov. Лідером опозищії самопроголошуе себе людина з найбільшим відсотком НЕДОвіри та АНТИрейтингу;

в) написання 3 великої літери слів у реченні (кількох або всіх): Stefaniva Vasylchyshyn. Великі Дипломати $і$ Люди із Великої Літери. Pavlo Dumashchin. Сильно аж за Душу Бере зі сльозами на очах. Ірина Галавін. Сергійчику, Ви Найкраший Прюдюсер. Я завжди Вашу Передачу Дивлюся Хто 3 Верху. Ми Любимо Вас I Божого Здоров'я Вашій Сім'ї!;

г) «слово у слові» (капслоком позначають весь відповідний формально-смисловий фрагмент):
Zinoviy Huzar. Маруся Звіробій-Біленька висунута Європейською Солідарністю, від бєнєблаЗЕнів буковельський Шевченко. Завязун Олександр. То, певно, якесь БОТОподібне. Володимир Стешенко. Розвивайтеся Духовно!!! Бо < .. > Творець Нам ДАРував Життя не для того, щуоби Ми його занедбали та витрачали на нісенітниці!!!

г) одне або кілька слів у реченні повністю написані капслоком: Ostap Drozdov. ЯК МИ МАСМО ГОВОРИТИ з ворогом і про ворога? Маруся Звіробій. Той, хто був тепер у судах, бачить, звучать прямо у вигляді звинувачень від прокурорів слова «ВІН БУВ В АТО, ТОМУ ВИНЕН!». Лікар Дубровський. Висновок, який є все більш очевидним, - КОВІД НЕБЕЗПЕЧНИЙ ДЛЯ ТИХ, У КОГО Е НЕЛІКОВАНІ, ЗАПУЩЕНІ ВАЖКІ СУПУТНІ ХВОРОБИ. Особливо ендокринологічні та сериево-судинні. Тому лікування, догляд та профілактика иих груп ризику і є головним ключем подолання важких наслідків на майбутне. А ПОЗА КОВІДОМ ті ж самі групи ризику $і \epsilon$ ГОЛОВНИМИ по структурі загальної смертності. Тому категорично не можна залишати иі групи населення без належної підтримки.

Водночас велика літера може використовуватися і для позначення словесного наголосу: $\underline{\mathbf{A н т о н}}$ Санченко. Ну щзо, ваші прогнози, хакнуть ТожеукрАінци УКФ, чи вже хакнули? Boris Polonski. Наприклад медвечуківсько-мураєвські канали, з одного боку, й прошенківські й пінчуківські, з другог, о запЕкло змагаються в тенденційності й пропаганді завдань свойх власників.

Сучасний етап розвитку інтернет-комунікації (а він, як уже було акцентовано, найчастіше має писемний характер) відзначається тим, що «ії учасники шукають способи адаптувати засоби розмовної мови до потреб писемної. Оскільки основною формою цього різновиду комунікації виступає писаний текст, iї учасники для втілення своїх інтенцій намагаються якомога ширше використовувати можливості графічної системи, часто виходячи за межі норми» (Андреєва, 2020: 8-9). Виразним прийомом у цьому аспекті $\epsilon$ такий поширений у Facebook прийом, як графічна деформація слова. Мотиваційною базою в цих процесах $\epsilon$ наявне в лексичній системі української мови слово. Дериваційна дія полягає в його графічній деформації. Дослідниця мови інтернет-комунікації Т. Андреєва вважає, що внесення до графічного образу слова відповідних змін відбувається для того, щоб пом'якшити ефект від сприйняття лайливого чи образливого слова або приховати його (адже через порушення правил спілкування в Мережі кожен користувач може бути заблокова- 
ний), і називає цей прийом «графічною евфемізацією» (Андреєва, 2020: 14).

Графічна деформація слова відбувається шляхом зміни графічного складу лексичної одиниці: автори таких неологізмів замінюють відповідні літери іншими літерами чи графічними знаками нелітерної природи. Останній різновид графічної деформації здійснюється із залученням значної кількості різнопланових засобів. Зокрема це:

a) крапки: Oleg Kozlov. Я то думав, щзо ти простий дурень, а ти виявлясться каца<...>ська гніда; Дмитро Буяло. Вадіку, заткнись вже, ватне ти $\boldsymbol{p}<. . .>л о$; Maria Shpak. Ватників $i$ жсо<...>лизів є до хрена. Амила Чистова. Але ж - вс<...>рюся, а не покорюся <..>. 䜣вь Тронищкая. Борисюк, а ией дебіл був $i$ залишається жс<...>м. Людмила Глебова. Доказів нема - одне гi<...>o! Mykola Volchko. Але Ви з такою підтримкою народу та з багажем знань так (особисто на мою думку) прос<...>ли таку можливість розвитку;

б) зірочки (asterisk): Сергій Гасвський. Ця пас**да ще хотіла вакиинувати украйнців расейською вакииною, хай сам нею лікується! Орест Каракевич. Хто підтримує Порошенка - всі "ск*ти», антимайданівиі $i$ m.d. Boris Polonski. Розсадник сінекурного непотизму й сор сячої агентури. Маруся Звіробій. Ви, як останні лош*ри, дали розвести себе історіями про баригу. Miško Brolis. Нехай жеруть своє ла*но. Олена Матушек. Рущак <...> абсолютно погоджуюсь!!! < ..> Але таке $2^{* * *}$ о на чолі організаиії усю ї̈ функиію перетворює на токсичну;

в) символ @ (ет): Любов Калитчук. Bu маєте особливий талант вляпатися $і$ нас решту затягнутив д@ny. Галина Гуськова. Смерть оккупантам-м@скалям. Руслан Чернобров. Це вже справжні бойові пі@араси!!! Яна Сте. Так правильно зробив! Шарія б ще. Всіх ӥх у ср@ку!

г) хеш (hash-«зинак решітки»): Igor Demchenko. Зараза, прокац\#пська. Через таких гнид в Украйні досі війна. Світлана Метльова-Загуменна. Маруся має бути у ВР, щзоб Зе обс\#рався приходячи туди зі своӥми промовками);

г) дефіс: Сергій Колісник. Шістка кремля, мабуть, пора вам на нараду до X-й-ла. Володимир Михайленко. Он Грач, кримський кому-їст, донюхався - Аксьонов його навіть на поріг не пускає. Mariva Gorodetskava. Кожного разу сподiваюся - дно, але пре3E-нm падає ще нижче;

д) коми / апостроф: Орест Каракевич. I вам абсолютно поф'г, що робив Маршал в ДАПі < ..> Добре, що не вороги Срмаки, в яких бізнес в РФ, р”ги та українофоби у ВР; е) символ \& (ampersand): Olha Moroz. Ця n\&дла московита говорила, що вони їхали в Україну, хахлов паднімать.

Рідше застосовуються інші графічні знаки: Руслан Т.Р.В. ПолҰдурок!!!; або цифра, яка нагадує їі конфігурацію: Nina Osmak. 8imaю!; трапляються випадки, коли до процесів графічної деформації залучено кілька різних графічних знаків: Олексій Сталкеров. Чи тобі нагадати, як обвинуваченого Цемаха, якого нама розвідка витягла на підконтрольну територію ціною життя О. Колодяжного, ти обміняв к@и*n@м!

Навмисне розривання слова теж є виявом графічної деформації: Ihor Zhowtyak. Верніть Пороха, кур..ви! Nona Zirka. Тьотя в дзеркало пялься. Там таке ж гівно як $і$ на тих к'аналах. Lesia Mudrak. Вищі сили тебе бережуть і підтримують! хай буде завжди затишно в своєму над...свідомому, під...свідомому...і-реальному cвimi!

Графічна деформація може відбуватися і шляхом скорочення базового слова. У процесі проведення цього дериваційного акту звичайно опускаються літери, що позначають голосні звуки. Водночас таке скорочення здійснюється до тієї межі, перехід якої не призводить до втрати впізнаваності плану вираження похідної одиниці: Stas Kozljuk. Тому, крва, майте до иієї роботи повагу! Ostap Drozdov. Опираючись на «мову ворожнечі», вживання слова «мскль" тягне на міжнаціональну ворожнечу/ Viktor Ilnytskyy. Внутрішньо Украӥна окупована не тільки мсклми а і ждми.

До такого явища, як графічна деформація слова, можна віднести випадки грамаредуплікації - багаторазового повторення окремої літери у слові. Цей прийом пов'язаний із тим фактом, що спілкування в соціальних мережах найчастіше відбувається шляхом продукування писемних текстів. Так створюється новий спосіб комунікації. Ії̈ план вираження нагадує усний різновид розмовного стилю. «Використання «знаків-символів», не властивих традиційній писемній мові, створення ефекту звукової мови, послуговування певними словесними формулами тощо наближають писемний різновид комунікації до його усного варіанта» (Дзюбіна, 2016: 77-78).

Т. Андреєва кваліфікує такі «деформовані слова» як репрезентанти «емфатичного наголошування», яке відбувається в результаті повторення відповідних літер (Андреєва, 2020: 14). Емфатичний наголос підсилює емоційний бік слова, виражає афективний стан мовця, робить відповідне слово емоційно насиченим (Матвієнко, 2016: 148). 
До окреслених процесів можуть залучатися:

а) літери, що позначають голосні звуки: Любов

Калитчук. Мдаааа, зеотаро, ви маєте особливий талант вляпатися. Діана Царук. Вітааалік, $я$ досі не можу відійти)). Orvsia Khimiak. Kaaйф! i персоналія і стільок. Свген Постолатій. Наркомаааани. Павло Шевело. То ж «спало на думку» мені видається більш влучним, з врахуванням ще й того, що, бува, думаєи-дуууумааєи, а результату - катма. Lesia Mudrak. Але я тебе дуууже відчуваю. Володимир Губенко. Тестостерооооооон!!! Марія Децик Петльована. Я проти референдумів! А те що канали тих чмиріків сепаратистських $і$ колаборандських закрили, вперше скажу, БРАВОООО!!! Киш Комот. Шаноооовні! Та не пийте ви ту воду з гірського поточка, там вище за течією - толока, $і$ коні, вони туди дьзююююрять! Людмила Гриценко. Люблюююююююю!!! Lesia Mudrak. A ие все-миииии! Ірина Костюк. Такиииий хорооооший день!;

б) літери, що позначають приголосні звуки: Konstantin Yevdokymenko. I взагалі, ну щзо такого, коли танчики уіу-уіу, і міни пщщцщ, це ж не під смерчем. Ostap Drozdov. А ось коли інтер- еси держсави здавати, то в них усе виходить

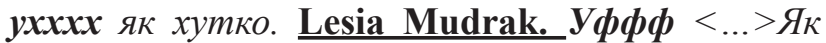
иього разу складно. Андрей Горбунов. Тому що Петя сцикуннннн!!!!

Зрідка обидва типи можуть поєднуватися: Костянтин Андріюк. Гууууххх! Нарешті з'ясували! Зрада/Перемога. Біжжжжииии, Вова, Біэжжжеии.

Висновки. Отже, поява інтернет-комунікації нової сфери використання мови - ставить перед мовною системою проблему іiі пристосування до нових умов існування, спричиняє відповідні зміни в лінгвосистемі, які найвиразніше помітні на рівні графіки. Для втілення власних інтенцій учасники інтернет-комунікації все частіше полишають межі наявних у мові норм, що може породжувати нову системність, закріплення як нормативних нових прийомів. Натепер комунікація в інтернеті (зокрема, у соціальних мережах) є тим полігоном, де випробовуються нові можливості графічної системи. Графічні маніпуляції з формою слова мають різноплановий характер. Вони демонструють багатий потенціал, наявний у графічній системі мови.

\section{СПИСОК ВИКОРИСТАНИХ ДЖЕРЕЛ}

1. Андреєва Т. М. Вихід за межі системності: інновації у графічному оформленні мережевої комунікації (на матеріалі ФБ-коментарів). Сучасні міжнародні відносини: актуальні проблеми теорії $i$ практики : матеріали Міжнародної науково-практичної конференції. Київ : Національний авіаційний університет, 2020. C. $7-16$.

2. Андрєєва Т. М. Специфіка мови Інтернету: капслокізація у ФБ-коментарях. Science and Education a New Dimension. Philology. 2019. № VII (57). Iss. 191. P. 7-10.

3. Дзюбіна О. І. Структура, семантика та прагматика сленгових неологізмів соціальних мереж Twitter тa Facebook (на матеріалі англійської мови) : дис. ... канд. філол. наук: 10.02.04. Львів, 2016. 206 c. URL: https://www.lnu.edu.ua/ wp-content/uploads/2016/05/dis_dzyubina.pdf.

4. Замальдинов В. Е. Неузуальные способы создания словообразовательных инноваций в интернет-пространстве. Вестник Пермского начионального исследовательского политехнического университета. Серия "Проблемы языкознания и педагогики». 2020. № 2. С. 80-89.

5. Матвієнко В. В. Просодичні засоби - наголос. Труди Київської духовної академії. 2016. № 16. С. 140-149.

6. Мельник С. М. Графодеривація в українській постмодерністській прозі. Наукові записки Національного університету «Острозька академія». Серія «Філологічна». 2014. Вип. 46. С. 121-123. URL: http://nbuv.gov.ua/UJRN/ Nznuoaf 20144637.

7. Тепшич А. І. Мовна гра як домінанта постмодерного дискурсу (на матеріалі прозових творів представників станіславського феномену) : монографія / наук. і відп. ред. А. П. Загнітко. Белград ; Вінниця : ТОВ «Нілан Лтд.», 2017. $192 \mathrm{c}$.

8. Штукарева Е. Б. Языковая специфика интернет-комуникации. Интернет коммуникаиия как новая речевая формация. Москва, 2012. С. 297-302.

\section{REFERENCES}

1. Andreyeva T. M. Vykhid za mezhi systemnosti: innovatsiyi u hrafichnomu oformlenni merezhevoyi komunikatsiyi (na materiali FB-komentariv) [Going beyond the system: innovations in the graphic design of network communication (based on FB comments)] Suchasni mizhnaroni vidnosyny: aktual'ni problemy teoriyi i praktyky : materialy mizhnarodnoyi naukovopraktychnoyi konferentsiyi. Kyyiv : Natsional'nyy aviatsiynyy universytet, 2020. S. 7-16 [in Ukrainian].

2. Andryeyeva T. M. Spetsyfika movy Internetu: kapslokizatsiya u FB-komentaryakh [Specifics of the Internet language: capslocation in FB-comments]. Science and Education a New Dimension. Philology. 2019. № VII (57). Issue: 191. P. 7-10 [in Ukrainian].

3. Dzyubina O. I. Struktura, semantyka ta prahmatyka slenhovykh neolohizmiv sotsial'nykh merezh Twitter ta Facebook (na materiali anhliys'koyi movy) : dys. ... kand. filol. nauk : 10.02 .04 [Structure, semantics and pragmatics of slang 
neologisms of social networks Twitter and Facebook (on the material of the English language): dis. ... cand. philol. Science: 10.02.04.] L'viv, 2016. 206 s. [in Ukrainian].

4. Zamal'dinov V. Ye. Neuzual'nyye sposoby sozdaniya slovoobrazovatel'nykh innovatsiy $\mathrm{v}$ internet-prostranstve [Unusual ways of creating word-formation innovations in the Internet space]. Vestnik PNIPU. Problemy yazykoznaniya i pedagogiki. 2020. № 2. S. 80-89. [in Russian].

5. Matviyenko V. V. Prosodychni zasoby - naholos [Prosodic drugs - emphasis]. Trudy Kyyivs'koyi Dukhovnoyi Akademiyi. 2016. № 16. S. 140-149 [in Ukrainian].

6. Mel'nyk S. M. Hrafoderyvatsiya v ukrayins'kiy postmodernist s'kiy prozi [Graphoderivation in Ukrainian postmodernist prose]. Naukovi zapysky Natsional'noho universytetu "Ostroz'ka akademiya". Seriya : Filolohichna. 2014. Vyp. 46. S. 121-123 [in Ukrainian].

7. Tepshych A. I. Movna hra yak dominanta postmodernoho dyskursu (na materiali prozovykh tvoriv predstavnykiv stanislavs'koho fenomena) : monohrafiya [Language game as a dominant of postmodern discourse (on the material of prose works of representatives of the Stanislavsky phenomenon): monograph]. Belhrad ; Vinnytsya : TOV "Nilan-LTD", 2017. 192 s. [in Ukrainian].

8. Shtukareva Ye. B. Yazykovaya spetsifika internet-komunikatsii [Language specificity of Internet communication]. Internet kommunikatsiya kak novaya rechevaya formatsiya. Moskva, 2012. S. 297-302. [in Ukrainian]. 